University of Nebraska - Lincoln

DigitalCommons@University of Nebraska - Lincoln

Journal for the Advancement of Developing

Economies

Economics Department

2014

\title{
Assessment of Land Use Dynamics and the Status of Biodiversity Exploitation and Preservation in Nigeria
}

\author{
Abiodun Elijah Obayelu \\ Federal University of Agriculture Abeokuta
}

Follow this and additional works at: https://digitalcommons.unl.edu/jade

Part of the Econometrics Commons, Growth and Development Commons, International Economics Commons, Political Economy Commons, Public Economics Commons, and the Regional Economics Commons

Obayelu, Abiodun Elijah, "Assessment of Land Use Dynamics and the Status of Biodiversity Exploitation and Preservation in Nigeria" (2014). Journal for the Advancement of Developing Economies. 7. https://digitalcommons.unl.edu/jade/7

This Article is brought to you for free and open access by the Economics Department at DigitalCommons@University of Nebraska - Lincoln. It has been accepted for inclusion in Journal for the Advancement of Developing Economies by an authorized administrator of DigitalCommons@University of Nebraska - Lincoln. 


\title{
Assessment of Land Use Dynamics and the Status of Biodiversity Exploitation and Preservation in Nigeria
}

\author{
Abiodun Elijah Obayelu \\ Federal University of Agriculture Abeokuta, Ogun State, Nigeria
}

\begin{abstract}
Land is the most important natural resource that affects every aspect of human life, while biodiversity constitutes the most important working component of a natural ecosystem. Land use and biodiversity are agricultural and ecological challenges presently facing Nigeria in her efforts at addressing the issue of agro-ecosystem transformation and sustainable land productivity. This study employed secondary sources of information to assess land reform act in Nigeria, the methodological framework to analyze the linkages between land use change and biodiversity, effects of land use on biodiversity, status of biodiversity and suggests ways to solving land use problems and biodiversity loss. Findings revealed climate change, invasive species, land conversion due to ignorance and high level of poverty as some of the drivers of biodiversity loss in Nigeria. Nigerians are altering the natural environment through continuing agricultural expansion and practices (conversion of forests to cultivated areas) although with the introduction of government led Presidential Initiative Afforestation program nationwide for regeneration. While competing land uses for agriculture and human settlements, rising demand for fuel wood and charcoal are contributing to the decline of forest and woodland areas; over-harvesting of resources and unregulated burning are also contributing to the decline of many species in the wild. In order to effectively implement many agreements, Nigeria had signed treaties with other international communities on conservation and sustainable use of biodiversity that conservation should be integrated into all forms of land use to promote cross-sectional cooperation among land users. It is imperative to check the pressures on protected areas in order to stem the tide of biodiversity loss. Planning for land use sustainability must consider the multiple and often competing environmental, economic and social values of a wide range of the public, decision makers, and interest groups.
\end{abstract}

Keywords: Sustainability, environmental change, reformation, intensification, diversification

\section{INTRODUCTION}

There has been an emerging recognition of important links between various global environmental issues such as loss of biodiversity, climate change and land use change/degradation. Land use reflects the dynamic processes between the earth's biophysical characteristics and human activities (Heistermann, et al., 2006). During the 20th century, land use dynamics emerged as a "global" phenomenon (Ramankutty et al., 2005). The process of development of mankind entails exploitation of natural resource with the purpose of converting it into usable form. Land is usually taken to include not only the physical soil, but also everything beneath and everything extending up to the sky above it (Adedipe, et al., 1991). Land provides source of income, livelihood, food security, cultural identity, and shelter. It is a basic asset for the economic empowerment of poor 
people and a safety net in times of hardship. It defines power relations between and among individuals and social groups and thus has enormous political implications. The two terms "land use" and "land cover" (LULC) sometimes refer to as "land change" are terms that are not the same thing (Jansen and DiGregorio, 2002; Comber, 2008). Understanding the driving forces, dynamics and directions of land use changes has therefore become key challenges for scientist. While land use is the term that is used to describe human uses of the land, or immediate actions modifying or converting land cover (Clawson and Stewart, 1965), land cover refers to the natural vegetative cover types that characterize a particular area or physical and biological cover over the surface of land, including water, vegetation, bare soil, and/or artificial structures. Biodiversity or biological diversity is defined by the convention on Biological Diversity as "the variability among living organisms from all sources including inter alia, terrestrial, marine and other aquatic ecosystems and the ecological complexes of which they are part; this includes diversity within species, between species and ecosystems" (Convention on Biological Diversity and United Nations Environment Program, 1992). In this paper, biodiversity is the full variety of life in an area, including diversity within species, between species, and among ecosystems. It includes not only plant and animal, as we commonly know them, but very importantly microorganisms (Okali, 2005), the diversity of genotypes, functional groups, communities, habitats and ecosystems (Meduna et al., 2009).

There are current evidences that humans have transformed significant portions of the Earth's land surface (Vitousek et al., 1997). Rapidly increasing human populations and expanding agricultural activities have brought about extensive land use changes throughout the world (Cunningham et al., 2005). Human beings have been modifying land to obtain food, shelter and other essentials of life for thousands of years, current rates, extents and intensities of such modifications are far greater than ever in history and continue undocumented (Misana et al., 2003). In many cases, most of the development activities are conducted in unplanned way leading to serious biodiversity loss and land degradation. At present, the change in land use, with both intensification and abandonment, and other environmental and socioeconomic processes at different scales (urbanization, tourism, pollution, global change, etc.) are important forces of environmental change (Chemini and Rizzoli, 2007). Access to land and land use is fundamental for the approximately 2.5 billion rural people in developing countries who depend on agriculture, forests, and forest products for their livelihoods (UNECOSOC, 2008). An awareness of the relationships between land use and biodiversity is therefore fundamental to understanding the links between people and their environment (HainesYoung, 2009).

The relationships between biodiversity and land use are complex and highly context dependent (Figure 1). Understanding the effects of land use on biodiversity and vice visa is very important in the planning for the sustainable management of natural resources. While in some places, specific land uses, or land management practices may be important in sustaining particular patterns of biodiversity; elsewhere, the uses to which land can be put are highly dependent on the biodiversity resources present. The single most important factor generating reduction in biodiversity is human land use / changes in land use practices (Catizzone et al., 1998). Natural resources are continuously being depleted due to continuous use of the resources and derivative activities of the populace. The findings from this study will assists in monitoring the dynamics of land use resulting from changing demand for land due to increasing population. Study of this nature is essential in order to fill the gaps in our knowledge of the relationships between land use and biodiversity, to increase the level of awareness of people and policymakers which is currently belief to be very low of the risks of 
uncontrolled biodiversity loss. People/ policy makers need to be well informed about the drivers of biodiversity loss and the levels of loss. They need to be informed of what is good and bad with the land reforms in Nigeria and about the current and expected trends in biodiversity change.

Based on the above background, the overall objective of this paper is to assess land use dynamics and the status of biodiversity exploitation and preservation in Nigeria. The specific objectives are to: review the concept of land use, land use changes, land covers and biodiversity; explain the methodological framework between land use dynamics and biodiversity; assess Nigeria's experience on land reform; examine the status of land use and biodiversity in Nigeria; explain the various factors influencing biodiversity loss in Nigeria; and suggest workable solutions to solving the land holding problems and biodiversity loss in the country.

\section{MATERIALS AND METHODS}

\section{The study area}

The study area is Nigeria. Nigeria is located in the western part of Africa between latitudes $4^{\circ} 16^{\prime} \mathrm{N}$ and $13^{\circ} 52^{\prime} \mathrm{N}$; and between longitudes $2^{\circ} 49^{\prime} \mathrm{E}$ and $14^{\circ} 37^{\prime} \mathrm{E}$. It occupies a total land area of $923,768 \mathrm{~km} 2$ with a population of over 170 million people (Central Intelligence Agency, 2013). By virtue of its geographical extent, it spans different climatic and ecological zones. The country is endowed with a very rich biodiversity. The mean annual rainfall ranges from about $450 \mathrm{~mm}$ in the northeast to about $3500 \mathrm{~mm}$ in the coastal southeast, with rains falling within 90 to 290 days respectively. The mean annual temperature ranges from $21^{\circ} \mathrm{C}$ in the south to $30^{\circ} \mathrm{C}$ in the north with extremes of $14^{\circ} \mathrm{C}$ and $45^{\circ} \mathrm{C}$ and an altitude range of $0-1000 \mathrm{~m}$ above sea level. At the current annual growth rate of $2.8 \%$, the country's population may reach about 180 million by the year 2020 . Consequently, the demand for food, fuel-wood and other biological resources will experience a corresponding increase, and this will lead to increased pressure on land, water and other resources.

\section{Methods of data collection}

This study involved bibliographic research in order to obtain insights about land use changes and biodiversity loss in Nigeria. Methods of data and information gathering involved the use of internet and grey literature. Many libraries and relevant federal ministries (ministry of Agriculture and Natural Resources, ministry of Environment) were visited from which numerous reports were collected. All documents were assessed for information regarding land resources, land use and biodiversity. Different land use classes in the Nigeria, land and biodiversity policies were obtained from various reports.

\section{Methods of data analysis}

Available data and information on land use and biodiversity in Nigeria were analyzed using descriptive statistics such as the distribution table.

\section{FINDINGS}

We observed ample theoretical evidence of the relationship between land use dynamics and status of biodiversity loss and preservation in Nigeria, but empirical evidences for most of these 
relationships are fragmented, meager or non-existent. This study pooled various facts and figures from literature and reports to know land use and biodiversity status and conservation in Nigeria.

Nigeria has a total land area of about 91077 ha (1000 square kilometers) as of 2010 and forest area of 9041ha (1000 ha). The country had 382,000 ha of planted forest between 1990 to 2010 and between this period lost an average of 409,650 ha or $2.38 \%$ of her forest cover per year adding up to about $47.5 \%$ of its forest cover, or around 8,193,000 ha (Tropical Rainforest news, 2011 and Table 2) as a result of activities such as farming, construction, and reckless destruction of forests at the rate of about 600,000 hectares per year (NEST, 1992). Other natural resources are becoming scarce as a consequence of environmental degradation, with loss of habitat as the major factor contributing to the depletion of these natural resources. Nomadic herding also contributes negatively to the depletion of the biota through over-grazing. The use of fire to suppress undesirable plant species has not been left out. Deforestation is also a serious problem in Nigeria, with forest loss occurring at an average rate of 3.3\% per annum. Since 1990, the country has lost over 6 million ha or $36 \%$, of its forest cover. Old-growth forests are disappearing at faster rate: between 1990 and $2005,79 \%$ of these forests were lost; and since 2000 , Nigeria has been losing an average $11 \%$ of its primary forests each year. These figures give Nigeria the highest deforestation rate of natural forest in the world. Every year a considerable part of the nation's forest resources is destroyed through industrialization, urbanization, road construction commercial agriculture, and other activities thereby disturbing the ecological balance that nature maintains with the living and nonliving resources. Unless there is solution to the pressures on biodiversity and lack of defined conservation / management program the threat to biodiversity sustainability in Nigeria is likely to continue in line with Lyam and Onyia (2009) observation.

In addition, results from this study have revealed that, several efforts have been made by the Nigeria government to both protect and preserve the nations' biodiversity through the establishment of agencies such as the Nigerian Conservation Foundation (NCF), the Federal Environmental Protection Agency (FEPA), the National Resources Council (NARECO) in collaboration with the United Nations Environmental Programme (UNEP) and the World-Wide Fund (WWF) and several others programs. The country also has some protected areas referred to as biosphere reserve. These include 8 national Parks, 445 forest reserves, 12 strict nature reserves and 28 game reserves to conserve wild life and to supplement protein from domestic sources (Nigeria first National Biodiversity Report, 2001).

\section{DISCUSSION}

\section{Status of biodiversity and land use change in Nigeria}

Nigeria is rich in biodiversity, with an array of fauna and flora found in the boundless forests and grasslands. This includes about 20,000 species of insects, almost 1,000 species of birds, 247 species of mammals, 123 species of reptiles, about 1,000 species of fish and about 7,895 species of plants (Federal Government of Nigeria 2001). There are about 7895 plant species identified in 338 families and 2,215 genera (Emma-Okafor et al., 2009). Nigeria has some 1417 known species of amphibians, birds, mammals and reptiles according to figures from the World Conservation Monitoring Centre. Of these, $1.2 \%$ is endemic, meaning they exist in no other country, and 3.5\% are threatened. Nigeria is home to at least 4715 species of vascular plants, of which $4.3 \%$ are endemic. Nobody knows for 
sure exactly how many species exist, or how rapidly species are disappearing through extinction. The loss of wild populations of plants is an indication of the loss of genetic resources that could potentially be used to improve crop qualities, such as disease resistance.

Land use in Nigeria has changed to more cultivated area and less bush, forests and grasslands. These changes have tremendously reduced areas with natural vegetation where in some sites there is hardly any natural vegetation. After the primary land cover conversion from natural vegetation to cultivation or grazing, land use becomes more complicated due to intensification and diversification as land for conversion becomes less and less available and farm sizes become smaller and smaller as a result of subdivision.

\section{A review of land reforms in Nigeria}

Land policy reforms are once again on the agenda of many African governments and their supporting donors. Land reform has moved up and down the ladder of development priorities over the past fifty plus years (Peters, 2007). Land reform is concerned with changing the institutional structure governing man's relationship with the land, involving intervention in the prevailing pattern of land ownership, control and usage in order to change the structure of holdings, improve land productivity and broaden the distribution of benefits. Land reform is an aggregate of ideas and courses of action designed to resolve tenure problems. The Federal Government promulgated in 1976 the Public Lands Acquisition (Miscellaneous Provisions) Decree to provide a cheaper basis for acquiring land for public purposes. Even though the government was able to acquire land for public purposes such acquisition could not be easily done at reasonable prices. Land litigations, disputes and communal clashes continued.

In essence, before the advent of the Land Use Act in 1978, the control and administration of land in Northern Nigeria was governed by the Nigerian Land Tenure Law 1962. Under this system, all lands in northern Nigeria were under the control and subject to the disposition of the Governor and were to be held and administered for the use and common benefit of the Natives of Northern Nigeria. Two titles to native land were recognized: customary rights of occupancy administered by traditional authorities which covered all those tenure systems administered by communities or their leaders since pre-colonial times; and statutory rights of occupancy which were administered by State Governments. A different scenario unfolded in Southern Nigeria where control over land was vested in families, clans, villages and communities. Certain features characterized the period before the advent of the Land Use Act. They included increased demand for land, subsequent increase in land prices, emergence of land speculators with several malpractices, land fragmentation encouraged by the customary land inheritance where land devolves to beneficiaries on the demise of the former owner or holder, prohibitive costs of land acquisition affecting government developmental projects, multiple and dubious sale of the same piece of land to different people resulting in litigations.

Each succeeding Federal Government since the promulgation of the Act had exhibited lack of political will to implement various provisions of the Act to make it succeed. The Act made allowance for transitional provisions for the orderly assimilation of the land tenure systems it hoped to replace, but other land tenure systems are still being operated. The National Council of State has never exercised its power to make regulations for the implementation of the Act as guaranteed by 
Section 46(1) of the Act. Specifically, the regulation to be made on term of the right guaranteed by the Act has not been made by the Council of States. Each state has thus been left to illegally legislate on the term of the grant of Statutory and even Customary Right of Occupancy contrary to the provisions of the Act, as no state can legislate on the Land Use Act.

Several factors are still obstructing the effective implementation of land use Acts as well conservation policies. There is the problem of lack of adequate data on the status of biodiversity and the extent of degradation in the country (FAO, 2000; USAID/Nigeria, 2008). Natural forests are being destroyed by other forms of land use, like agriculture, grazing and construction activities as a result of uncoordinated land use policy and rapid urbanization leading to desertification and degradation of the environment (FAO, 2000). There is evidence of land conversion to agriculture in some forest reserves without any serious effort by the authorities to stop the trend (USAID/Nigeria, 2008). Many of the program and activities aimed at achieving the objectives are not well designed or organized. For instance, the tree planting campaigns are not properly coordinated nationally. The situation is complicated by the problem of discontinuity in commitment to the policy. The rapid turnover of political leadership in the country has resulted in varying degrees of commitment to the implementation of programs. In the case of the tree planting campaign, while it was mostly neglected by some regimes, others made half- hearted attempts at reviving or promoting it.

Cultural factors have also continued to militate against effective conservation policy implementation in the country. In many communities in Nigeria, land is seen as a sacred property passed from one generation to another. Great opposition normally follows attempts by government to convert what is regarded as personal or communal property to reserves. Many laws on biodiversity and forestry are difficult to enforce because of the high level of poverty in the country (USAID/ Nigeria, 2008). A lot of people in both rural and urban areas depend on firewood and charcoal for cooking. Thus, the local trade in firewood and charcoal continue to thrive. The problem is aggravated by increasing food and fuel prices, which force more people to depend on forest resources for survival. Corruption among political office holders and implementing officials is another serious problem land use and biodiversity policies in Nigeria. Ecological funds meant for conservation and programs such as desertification and erosion control are often diverted to other uses, which are often personal.

The Federal Government of Nigeria established a Presidential Technical Committee on April 2, 2009 to undertake the reform of the land tenure situation in the country following the various problems emanating from the Land Use Act of 1978. That act conferred State Governors the custodian right to issue certificates of occupancy for landholders in their states but left out the majority already with possessory rights to their land. The present reform sets out essentially to rectify this and to provide registerable titles to all landowners in the country.

Ukaejiofo (2007) and Olayiwola and Adeleye (2006) show that traditional tenure system placed major constraints upon the achievement of efficient agricultural production and physical development, which led to land use act - promulgation by the government in 1978. This land use act promulgation by the government 30 years ago failed to take into sufficient consideration the modifications that have taken place in the traditional tenure system by treating land as a free good. Most elements of the Act are disregarded by the majority of the landowners. Sales of land, forbidden 
by the Act, have been on increase in Nigeria. The Act has not mitigated land speculation; rather it has driven it underground or exacerbated it.

In 2009, there was the inauguration of Presidential Technical Committee on Land Reform with a seven-point term of reference. The references were to (1) collaborate and provide technical assistance to States and Local Governments to undertake land cadastral nationwide, (2) determine individuals" "possessory" rights using best practices and most appropriate technology to determine the process of identification of locations and registration of title holdings, (3) ensure that land cadastral boundaries and title holdings are demarcated in such a way that community, hamlet, village, village area, town will be recognizable, (4) encourage and assist States and Local Governments to establish an arbitration mechanism for land ownership conflict resolution, (5) make recommendations for the establishment of a National Depository for Land Title Holdings and Records in all States of the Federation and the Federal Capital Territory, (6) make recommendations for the establishment of a mechanism for land valuation in both urban and rural areas, in all parts of the Federation, and (7) make any other recommendations that will ensure effective, simplified, sustainable and successful land administration in Nigeria.

\section{Land Use Dynamics in Nigeria and their Effects on Biodiversity}

Land remains a gift of nature to man and the most important factor of production. In its physical form, land is immoveable and it products however can be moved from one part of the globe to another. Land use is defined as the arrangements, activities and inputs people undertake in a certain land cover type to produce, change or maintain it. This definition of land use establishes a direct link between land cover and the actions of people in their environment (DiGregorio and Jansen, 2005). It describes how a portion of the earth's surface is used by man (such as for industry, habitation, agriculture, etc.). Since the environment is progressively dynamic in response to the use man puts it, when the environment reacts, it is simply readjusting to the changes which either sustains or degrades it. Land use change on the other hands, is the use of a particular land from one form to another over time, (e.g., from natural vegetation/ forest to cultivation; cultivation to grazing or from swamp to cultivation). The total land area under protection in Nigeria is found as 92,377 ha; 2,429,241 ha in sub-Saharan Africa and 13,328,979ha in the world; (IUCN, 2003). Also observed is the fact that, the main land use in Nigeria is rain-fed agriculture. Other land uses include extensive grazing (pastoralism) and irrigated system along the alluvial plains (most common in the northern Nigeria), and wood collection. Rain-fed agriculture is practiced in combination with pastoralism and wood collection. Cultivation of irrigated crops involves grain and vegetableoriented activity. Supplementary water for irrigation is obtained from wells, dams and other water bodies. Wood collection for charcoal production is rampant and occurs in all areas with abundant trees such as the southern rainforest and the humid agro-ecological zones of Nigeria. Land use reduces ecosystem complexity and diversity by replacement of more complex natural vegetation with less complex agro-ecosystem with fewer species.

The effects of land use changes in Nigeria have affected biodiversity through conversions of land cover from natural vegetation. People clear natural vegetation to create farmlands and for livestock grazing. The area devoted to grazing in the Nigeria for instance, rose from 166, 326km2 in 1978 to 187, 236km2 in 1995 (Nigeria first National Biodiversity Report, 2001). Because most of the cattle are concentrated in the semi-arid zones that support $90 \%$ of cattle, the area is subjected to 
overgrazing, and shortage of fodder. This has resulted into loss of native species (like leopard, crocodile, monkeys, antelope, tropical fish, birds and other reptiles) in natural habitats, exposure of soils to water and wind erosion, reduction in shade on soils, and increase in abundance of unpalatable grasses and introduction of new species. Change from one cultivation type to another such as from mono crop to mixed crops and vice versa; from annual crops to perennial crops and vice versa leads to variations in the amount of cover resulting to soil erosion.

\section{Drivers of Land Use Change and Biodiversity Loss in Nigeria}

A driver is any natural or human-induced factor that directly or indirectly causes a change in ecosystem (MEA, 2005). Several studies have identified some factors (drivers) affecting land use change and biodiversity conservation in Nigeria. The drivers of land use change and those of biodiversity are similar. For instance, while those of land use change include increases in the human population and density, poor economic status in form of high level of hunger and poverty, increase in productivity, higher income and consumption patterns, technological, political and climate change (Table 2); those affecting biodiversity include: (1) land clearing for agriculture and uncontrolled logging, (2) gathering of firewood (Asibey and Child, 1990); (3) overgrazing and deforestation, (4) indiscriminate or ill-planned bush burning, (5) high population rate and illegal hunting for bush meat (Agbelusi, 1994), (6) shape of the landscape, drainage, vegetation and soil types (Ayodele and Lameed, 1999), (7) public policies (perverse policies that provide incentives which degrade biodiversity, (8) failure to incorporate the monetary value of biodiversity into decision making and (9) failure to integrate biodiversity concerns as a transversal element into policy. The slow drivers as shown in Table 2 result in gradual impacts over decades, and the fast drivers have impacts in one year.

Indicators of the direct drivers include increasing rate of fertilizer usage, water consumption and irrigation while those for indirect drivers include: invasion by non-native species, climate change, and land cover conversion, and landscape fragmentation (Millennium Ecosystem Assessment, 2005). Some of the important direct drivers affecting biodiversity in Nigeria are discussed below.

Habitat destruction: The greatest human impact on biodiversity is the alteration and destruction of habitats, which occurs mainly through changes in land use: draining of wetlands, clearing of land for agriculture, felling of forests for timber, road construction and pollution of the environment and fragmentation. Destruction of natural habitats has continued in Nigeria resulting in the depletion of biodiversity (Imeht and Adebobola, 2001). A report had shown that habitat destruction and deforestation have threatened the country biodiversity status with extinction of 484 plant species in 112 families of 4600 plant species in Nigeria (Okojie, 1999) where between 70 and $80 \%$ of original forest has disappeared. The introduction of cash crops like cocoa, coffee, rubber, cotton, groundnut and oil palm into the farming systems since the 1900s was a big impetus for massive deforestation of the natural ecosystems. Nile crocodile which was once found in the Nigerian coastal waters right up to Lake Chad is fast disappearing due to loss of habitat and the hunting of crocodile for their meat, egg, hide and skin (Imeht and Adebobola, 2001). Also, in Southern Nigeria, the forest elephant, chimpanzee, leopard, yellow- backed duiker, the Royal python, the Nigeria quenon are among the animals on the endangered list. 
Climate change driver: Natural variations in climate are among the more important causes of past changes in biodiversity. Climate change affects the nature of ecosystems and the habitats that support life. It threatens ecosystems that have already been weakened by other human activities such as pollution, development, and overharvesting of natural resources. Climate change is increasingly affecting all aspects of biodiversity, from individual organisms, through populations and species, to ecosystem composition and function. It has led to a decrease in water availability and quality, increase in the risk of floods and droughts, decrease in reliability of hydropower and biomass production and increase incidence of vector-borne diseases in Nigeria. In many parts of Nigeria, tropical forest and rangelands are already under threats as a result of climate change. Southern and eastern parts of Nigeria at many times experienced heavier and steadier rainfall leading to increasing rainfall-induced erosion. Conversely, in the arid northern part of Nigeria, higher temperatures contribute to dry conditions which underlie accelerated wind erosion. Sea level is also accelerating thereby adversely affecting cropland, surface and underground water resources, transportation, residential and industrial layouts, land-based recreational activities and numerous other land use activities.

Overexploitation and invasive species: These have been important as well and continue to be major drivers of changes in biodiversity. Among the most commonly overexploited species or groups of species are marine fish and invertebrates, trees, and hunted animals for meat. Some exotic and indigenous invasive species are ravaging coastal mangrove swamps. Nipa palm, water hyacinth, and other exotic plant species have deleterious effects on native biodiversity. Water hyacinth, for example, has invaded more than 2,000 sq. km of fresh water, cutting off villages, rendering local fishermen jobless, and degrading aquatic habitats in Nigeria (Nigerian Environmental Analysis Report, 2002). Similarly, high level of hunger in Nigeria (ranked 40th out of 79 on the 2012 Global Hunger Index and 156th out of 187 on the 2011 United Nations Development Programme Human Development Index) as well as high rate of poverty (69\% of the country's total population living in relative poverty) (Yemi, 2012) have put many Nigerians to the position of exploiting natural resources for survival.

Nutrient loading/pollution: The widespread increase of various pollutants and poisonous or toxic substances in the environment has had obvious local impacts on biodiversity in acutely affected areas. Oil exploration in the Niger Delta and in coastal areas, gas emissions and other pollutants from the petroleum industry have caused considerable environmental pollution and forest degradation thus biodiversity. Heavy metals and persistent organic pollutant such as polychlorinated biphenyls, dioxins and DDT (dichlorodiphenyltrichloroethane) are of particular concern since they do not degrade easily in the environment. They accumulate and are lethal to plants, animals, fishes and human-beings resulting to loss of species and ecosystem disruption.

Economic Drivers: Increase in economic activity leads to rising per capita income and demand for many ecosystem services grows. The failure of the economic system to internalize externalities leads to the continuation of environmentally damaging activities. If externalities are uncorrected then markets fail: they generate prices that do not reflect the true cost to society of our economic activities.

Demographic change drivers: Although from a theoretical point of view the relation between population pressure and the impact on biodiversity is almost obvious, no systematic attempt has 
been made so far to analyze this relationship in a quantitative way. The most recent fact about population growth rate of Nigeria is about 2.54per annum (Central Intelligence Agency, 2008). The country's population explosion put at about 170million (National Population commission, 2013) has resulted in the increase of human habitats and rapid development of industries; people are struggling to fill up of water bodies for construction of dwelling places to meet the needs of the ever-rising population thereby leading to loss of various species of crops and even fishes (Swingland, 2003). There is also exploitation of non-timber forest products for food, medicine, oil, fuel, wood, furniture, and building material resulting in loss of biodiversity.

Socio-political Drivers: Socio-political drivers encompass the forces influencing decision- making and include the quantity of public participation in decision-making; the groups participating in public decision-making; the mechanisms of dispute resolution; the role of the state relative to the private sector; levels of education and knowledge. These factors in turn influence the institutional arrangements for ecosystem management, as well as property rights over ecosystem services. In Nigeria for instance, the Niger Delta region of Nigeria (consisting of nine states in southern part of the country) is riddled with development crisis consequent upon environmental changes and destruction of aquaculture. Such bodies as the Movement for the Survival of the Ogoni People (MOSOP), Ijaw Youth Congress (IYC), Egbesu Youth, and the Niger Delta Volunteer Force (NDVF), are all seen to typify southern minority responding to environmental degradation, political marginalization, and economic underdevelopment of the Niger Delta.

Cultural and Religious Drivers: These are the values, beliefs, and norms that a group of people share. Individuals' perception influences what they consider important and suggests what courses of action are appropriate and inappropriate. Cultural factors influence consumption behavior (what and how much people consume) and values related to environmental stewardship or change. In Nigeria, cultural practices that encourage the use of specific species for festivals often limit the population of species particularly occurring under narrow ecological range. In some cultures, in Nigeria, hunting expeditions is restricted to some woodland. It is an offence for anybody to hunt to any of these sites before it is announced. This allows vegetation and animal species to regenerate before subsequent disruption by man. In some villages, species of acacia could not be felled, unless certain rituals were performed by an elderly person involving having some grains underneath such trees. In the Southern part of Nigeria, there are also some forests referred to as "evil forest" where hunting or tree felling does not take place. These in a way assist in the prevention of biodiversity loss.

Science and Technology: The development and diffusion of scientific knowledge and technologies that exploit that knowledge has profound implications for ecological systems. Technological advancement affects ecosystem services in terms of increasing food production but at the same time leads to loss of biodiversity. In all cases, habitat and land use change have had the biggest impact on biodiversity across biomes. The use of only improved varieties of crops and the complete neglect of local varieties and the land races had led to loss of biodiversity in Nigeria (Emma-Okafor et al., 2009). A major example of this is the use of improved okra (Abelmoscus esculentus) in place of the native tall okra (A. caillei) that is popularly known to be sensitive to day-length. Local varieties such as the African yam bean (Sphenostylis stenocarpa) are now becoming extremely rare, as only improved cowpea (Vigna unguiculata) is being cultivated in many farms. 


\section{CONCLUSION AND COMMENDATIONS}

There are a number of major issues at the interface of biodiversity and land use. Human transformations of land cover and land use is the key driver of the loss of biodiversity and ecosystem services in Nigeria. Biodiversity does not only have an ethical and cultural value but plays a role in ecosystem function and is essential to economic production and human wellbeing. Land, the basic resource that supports production of all agricultural commodities is becoming scarce. The main pressure includes: unsustainable use and overexploitation; global climate change; demographic and technological changes. Climate change is gradually changing the relationship of land use and biodiversity with some parts becoming drier and others wetter. There is increasing rate of erosion, flooding and carbon dioxide in the atmosphere which is contributing to global warming. A major change is noted with respect to the change from forest to other land uses which affects biodiversity and the concept of sustainable development. The removal of forest cover during logging has in some instances resulted in the scarcity or outright extinction of many important plant and animal species.

In order to overcome the problem of land use changes in Nigeria, land use decisions must:

1. Take into consideration the relationship of adjacent land uses and integrate proposed land uses with existing natural and physical environments;

2. Recognize that intensive land use without appropriate soil management practices leads to environmental degradation;

3. Encourage programs that have objective of making more arable lands available through restoration of already degraded and impoverished lands;

4. Once governments decide to act to protect biodiversity, they need to choose policies that reflect the relative value people place on it;

5. Integrated Crop and Pest Management (ICPM) programs should be introduced by ministry of Agriculture in Nigeria to avoid the use of toxic, synthetic, non-biodegradable agrochemicals and their lethal effects on biodiversity in the ecosystem;

6. Laws and regulations, economic instruments and incentives, education and training, should all enhance the social and economic incentives to preserve biodiversity;

7. Identify and reduce conflicts at different scales, and build up a large consensus on the value of biological diversity;

8. It is also necessary to control the rapid rate of destruction of wild animals especially with the increasing danger of extinction of some species by creating more game reserves which could turn such areas into tourist centers;

9. There is a need to check the pressures on protected areas in order to stem the tide of biodiversity loss. 
10. Planning for land use sustainability must consider the multiple and often competing environmental, economic and social values of a wide range of the public, decision makers, and interest groups;

11. A new approach to forestry resources conservation in Nigeria is required through enforcement and a community-based approach.

\section{REFERENCES}

Adedipe, N. O (1991): "Environmental and technical support factors for large - scale farming in Nigeria". National seminal on large-scale farming. Federal Ministry of Agriculture and National Resources, Lagos.

Agbelusi, E.A. (1994): Wildlife Conservation in Ondo State. The Nigerian Field 59: 73-83.

Alimi, T., Ajewole, O.C., O.O. Olubode-Awosola, O. O., Idowu, E. O., (2006); Economic rationale of commercial organic fertilizer technology in vegetable production in Osun State of Nigeria. Journal of Applied Horticulture; p159-164, July-Dec., 2006.

Asibey, E.A.O. and Child, G. (1990): Wildlife Management for Rural Development in SubSaharan Africa. Unasylva; 41: 3-10

Ayodele, I.A. and Lameed, G.A. (1999): Essentials of Biodiversity Management. Powerhouse Press and Publishers, Ibadan, Pp 74.

Baillie, J.E., Hilton-Taylor, C., Stuart, S.N. (2004): A Global Species Assessment. Gland, Switzerland: The world conservation Union

Catizzone M, Larsson T.B. and Svensson L. (1998): Understanding Biodiversity - An agenda for research into biodiversity prepared by the European Working Group on Research and Biodiversity. European Commission Ecosystems Report 25, EUR 18444 EN

Chemini C. and A. Rizzoli (2007). Land use change and biodiversity conservation in the Alps. Journal of Mountain Ecology; 7(supplementary):1-7.

Central Intelligence Agency (2013): Population growth rate (percentage), 2013 Country Ranks, By Rank.

Clawson, M. and C L. Stewart (1965): Land use information. A critical survey of U.S. statistics including possibilities for greater uniformity: Baltimore, Md., The Johns Hopkins Press for Resources for the Future, Inc., $402 \mathrm{p}$.

Comb A. J. (2008): The separation of land cover from land use with data primitives. Journal of Land use Science; 3(4): 215-229.

Convention on Biological Diversity and United Nations Environment Programme (1992): Handbook of the Convention on Biological Diversity. Earthscan Publications Limited, London, United Kingdom

Cunningham, W. P., Cunningham, M. A., and Siago, B. (2005): Environmental science: a global concern. New York: McGraw - Hill.

DiGregorio A and Jansen L. J. M. (2005): Land Cover Classification System. Classification Concepts and User Manual. Software Version 2. FAO Rome.

Emma-Okafor L. C; Ibeawuchi I. I., and C.J. Obiefuna (2009): Biodiversity Conservation for Sustainable Agriculture in Tropical Rainforest of Nigeria. New York Science Journal; 2(7): $81-88$

FAO (2000): Country Report: Nigeria. Forestry Outlook Study for Africa (FOSA). Retrieved online at http://www.fao.org/docrep/004/AB592E/AB592E02.htm. 
FGN (2001): First National Biodiversity Report, July 2001. Retrieved online at http://www.cbd.int/doc/world/ng/ng-nr-01-en.pdf

Haines-Young, R. (2009): Review Land use and biodiversity relationships. Land Use Policy 26S (2009) S178-S186

Iment. N and Adebobola N. (2001): The effects of poverty in conservation of Biodiversity: The Nigeria Experience. Retrieved online at http://www.scienceinafrica.co.20

IUCN (2003): The Durban Accord. 5th World Parks Congress of the International Union for the Conservation of Nature (IUCN) on "Benefits Beyond Boundaries", Durban, 2003. Retrieved online from www.iucn.org/wpc2003.

Jansen, L. J. M., and A. Di-Gregorio (2002): Parametric land cover and land-use classifications as tools for environmental change detection. Agriculture, Ecosystems \& Environment 91:89100.

Heistermann, M., Muller, C. and K. Ronneberger (2006): Land in sight? Achievements, deficits and potentials of continental to global scale land-use modeling. Agriculture, Ecosystems and Environment; $114: 141-158$

Okali, D.U.U, (2005): "Biodiversity and Poverty Alleviation"; NEST, Ibadan; 2005

Lambin E.F., Geist H. and E. Lepers (2003). Dynamics of land use and cover change in tropical regions. Annual Review of Environment and Resources; 28:205-241

Lyam P. and C. Onyia (2009): Barcoding Threatened Plant Species of West Africa: Nigeria as Case Study. Paper presented at the 3rd International Barcode of Life Conference Nov. 7th13th 2009 at Mexico City.

MEA (Millennium Ecosystem Assessment) 2005: Ecosystems and human well-being: biodiversity synthesis. World Resources Institute, Washington, D.C. Available from http://www.millenniumassess ment.org//en/Products.Synthesis.aspx

Meduna A.J., Ogunjinmi A.A. and S.A. Onadeko (2009): Biodiversity Conservation Problems and Their Implications on Ecotourism In Kainji Lake National Park, Nigeria. Journal of Sustainable Development in Africa; 10 (4): 59-73

MEA (Millennium Ecosystem Assessment) 2005: Ecosystems and Human Well-being: Biodiversity Synthesis, Chapter 3, p.49

Misana, S. B., Majule A. E., Lyaruu H.V (2003): Linkages between Changes in Land Use, Biodiversity and Land Degradation on the Slopes of Mount Kilimanjaro, Tanzania. LUCID's Land Use Change Analysis as an Approach for Investigating Biodiversity Loss and Land Degradation Project. LUCID Working Paper Number: 38.

NEST (1992): "The Challenges of Sustainable Development in Nigeria". Report prepared for the United Nations Conference on Environment and Development, 1st-12th, June, 1992, Rio De Janeiro, Brazil. Pp.152-172.

Nigeria National Biodiversity Report (2001): Nigeria: First Biodiversity Report, July 2001. Retrieved online from http://www.cbd.int/doc/world/ng/ng-nr-01-en.pdf

Nigeria Environmental Analysis (2002): Nigeria Environmental Analysis Final Report. Retrieved online from http://www.scribd.com/doc/27554782/Nigeria-Environmental- Analysis-FinalReport.

Okojie, J. A. (1999): Environment Resources Management and Education in Nigeria: An Agenda for Change. Annual Lecture Series, Science Teachers Association of Nigeria. 33pp

Olayiwola, L. M. and O. Adeleye (2006): Land Reform - Experience from Nigeria. Paper presented at Promoting Land Administration and Good Governance 5th FIG Regional Conference Accra, Ghana. 
Peters P.E (2007): Challenges in Land Tenure and Land Reform in Africa: An Anthropological Perspective. Center for International Development (CID) Working Paper No. 141 March 2007. Harvard University.

Ramankutty N, Archard F, Aves D, Turner B.L, Defries R, Goldewijk K.K, Graumlich L, Reid R.S (2005). Global Changes in Land Cover. Update Newsletter of the International Human Dimensions Programme on Global Environmental Change, 03/2005, pp. 4-5.

Swingland I.A.N.R (2003). Capturing carbon and conserving Biodiversity: the market approach. Earthscan Publications Limited.

Tropical Rainforest News (2011): Nigeria Forest Information and Data, 2011 update. Retrieved online from http://rainforests.mongabay.com/deforestation/2000/Nigeria.htm

Ukaejiofo, N. (2007) The future of Land Administration in Nigeria. A paper presented at the Cambridge Conference Held at St. John College Cambridge, United Kingdom, July 15-20

UNECOSOC (United Nations Economics and Social Council) 2008: "Land and Vulnerable People in a World of Change". Issues Paper of ECOSOC Preparatory Meeting. Available online at http://www.un.org/en/ecosoc/docs/programme/ecosocprepmtgissuespaper.pdf USAID/Nigeria (2008): Nigeria Biodiversity and Tropical forestry assessment: Maximizing Agricultural Revenue in Key Enterprises (Markets). Chemonics International Inc.

Vitousek P.M, Mooney H.A, Lubchenco J, Melillo J.M (1997): Human Domination of Earth's Ecosystems. Science 277:494 to 499.

\section{APPENDIX}

Table 1: Trends in Total (Net) Forest Cover, Natural Forest Cover, Primary or Old Growth Forest Cover and Planted Forest Cover, 1990-2010

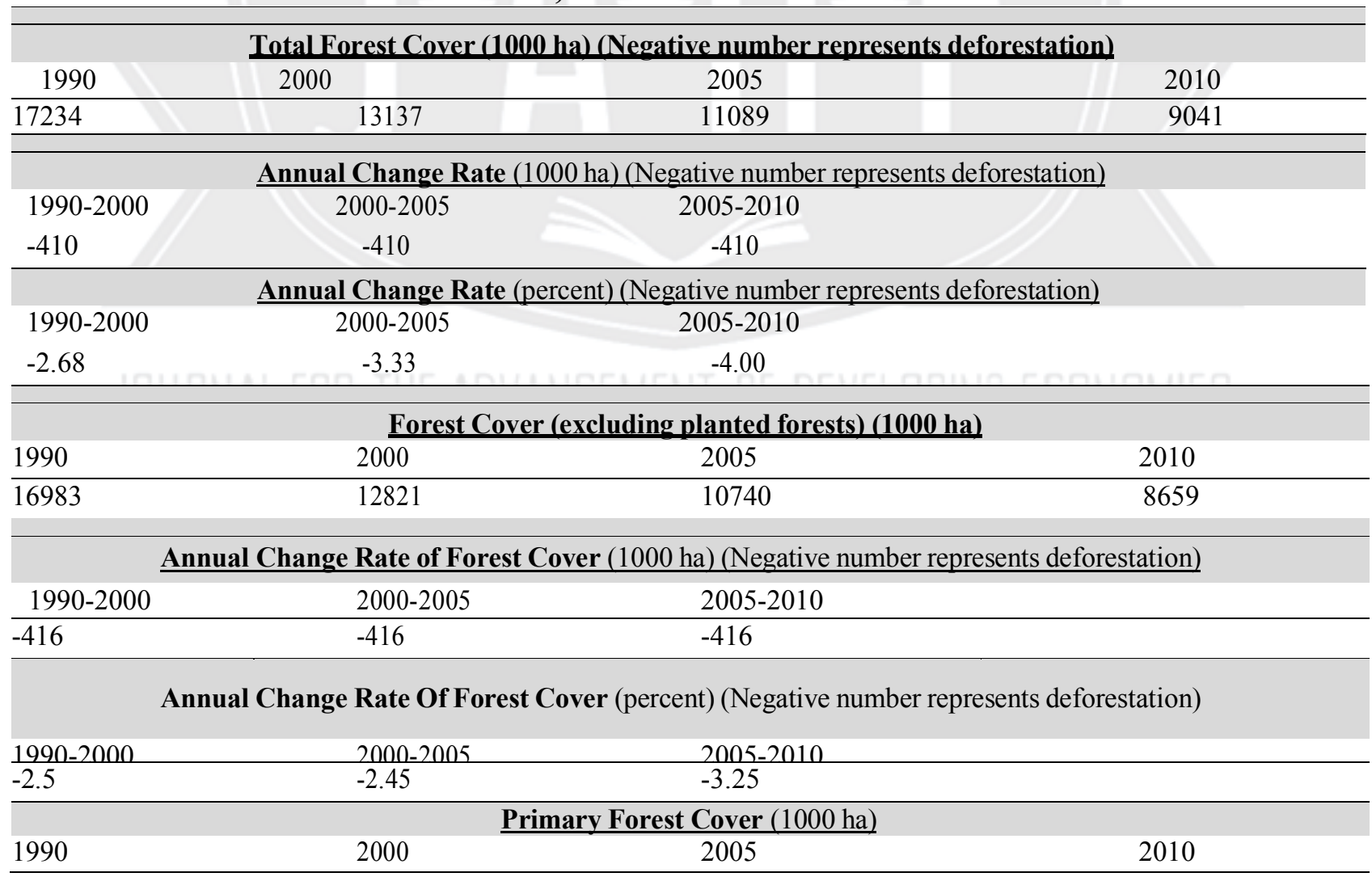




\begin{tabular}{|c|c|c|c|}
\hline 1556 & 736 & 326 & n.s. \\
\hline \multicolumn{4}{|c|}{ Annual Change Rate of Primary Forest Cover (1000 ha) (Negative number represents deforestation) } \\
\hline $1990-2000$ & $2000-2005$ & $2005-2010$ & \\
\hline-82 & -82 & -65 & \\
\hline \multicolumn{4}{|c|}{ Annual Change Rate of Primary Forest Cover (percent) (Negative number represents deforestation) } \\
\hline $1990-2000$ & 2000-2005 & $2005-2010$ & \\
\hline-7.21 & -15.03 & - & \\
\hline \multicolumn{4}{|c|}{ Planted Forest Cover (1000 ha) } \\
\hline 1990 & 2000 & 2005 & 2010 \\
\hline 251 & 316 & 349 & 382 \\
\hline \multicolumn{4}{|c|}{ Annual Change Rate of Planted Forest Cover (percent) (Negative number represents deforestation) } \\
\hline $1990-2000$ & $2000-2005$ & $2005-2010$ & \\
\hline 7 & 7 & 7 & \\
\hline \multicolumn{4}{|c|}{ Annual Change Rate of Planted Forest Cover (percent) (Negative number represents deforestation) } \\
\hline $1990-2000$ & $2000-2005$ & $2005-2010$ & \\
\hline 2.33 & 2.01 & 1.82 & \\
\hline
\end{tabular}

Source: Tropical Rainforest News (2011)

Table 2: Drivers of land-use change

\begin{tabular}{l|l|l|l|l|l|l|l|l|l}
$\begin{array}{l}\text { Changes in human } \\
\text { population and } \\
\text { management }\end{array}$ & $\begin{array}{l}\text { Changing } \\
\text { opportunities }\end{array}$ & created by markets & Policy and political & changes \\
\hline
\end{tabular}

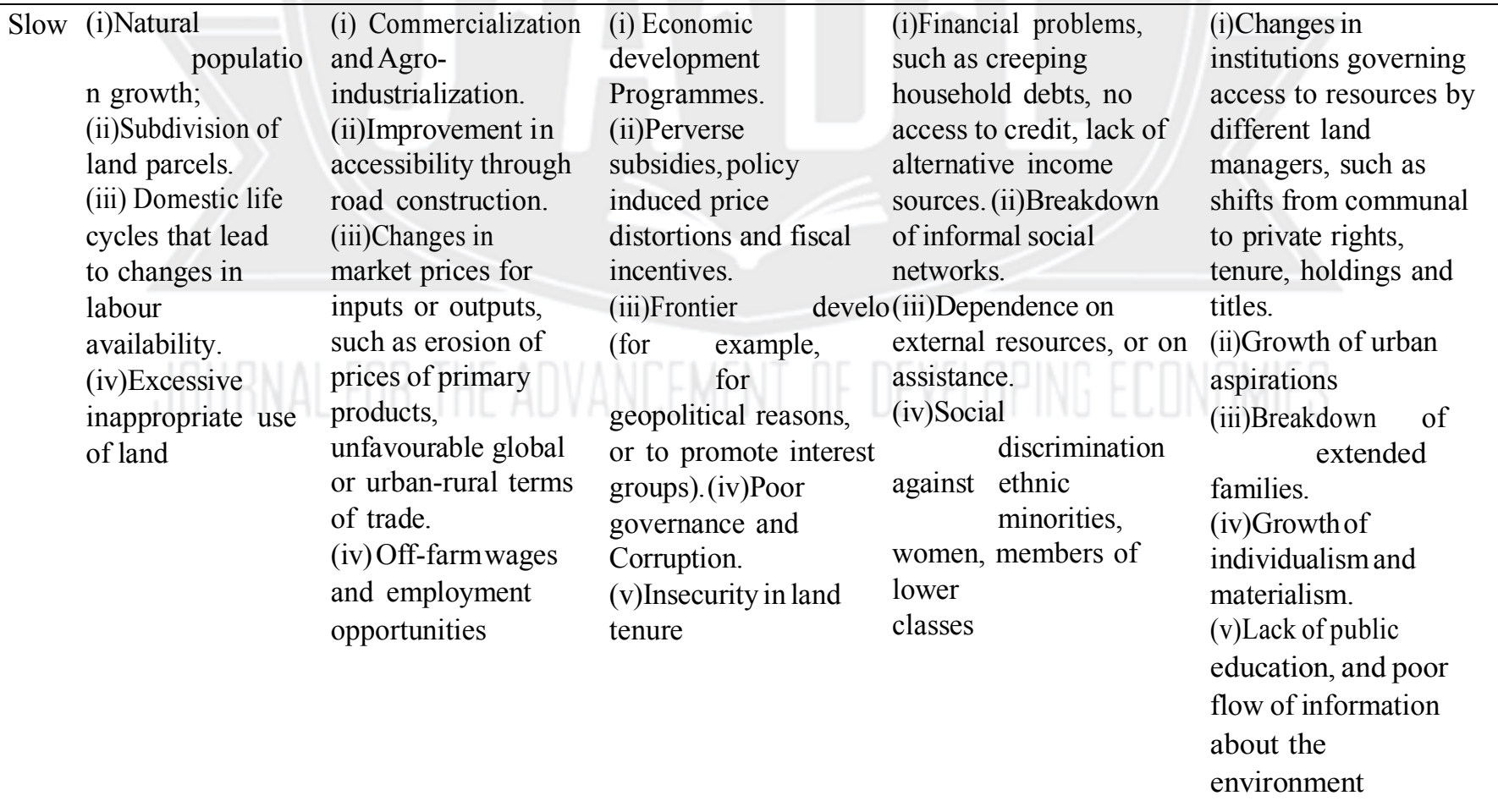


Fast (i)Spontaneous migration,

ii) forced population displacem ent

iii) Decrease in land availability due to encroachment of other uses such as natural reserves (i) Capital investments. (i) Rapid policy changes, such as devaluation

(ii)Changes in national or global macro-economic and trade conditions that lead to changes in prices, such as a surge in energy prices, or global financial crisis.

(ii)Government instability. War

(ii)Diseases, such as malaria, and illnesses such as HIV/AIDS

iii) New technologies for intensification of resource use

(i)Internal conflicts.

(i)Loss of entitlements to environmental resources through expropriation for largescale agriculture, large dams, forest projects, tourism and wildlife conservation

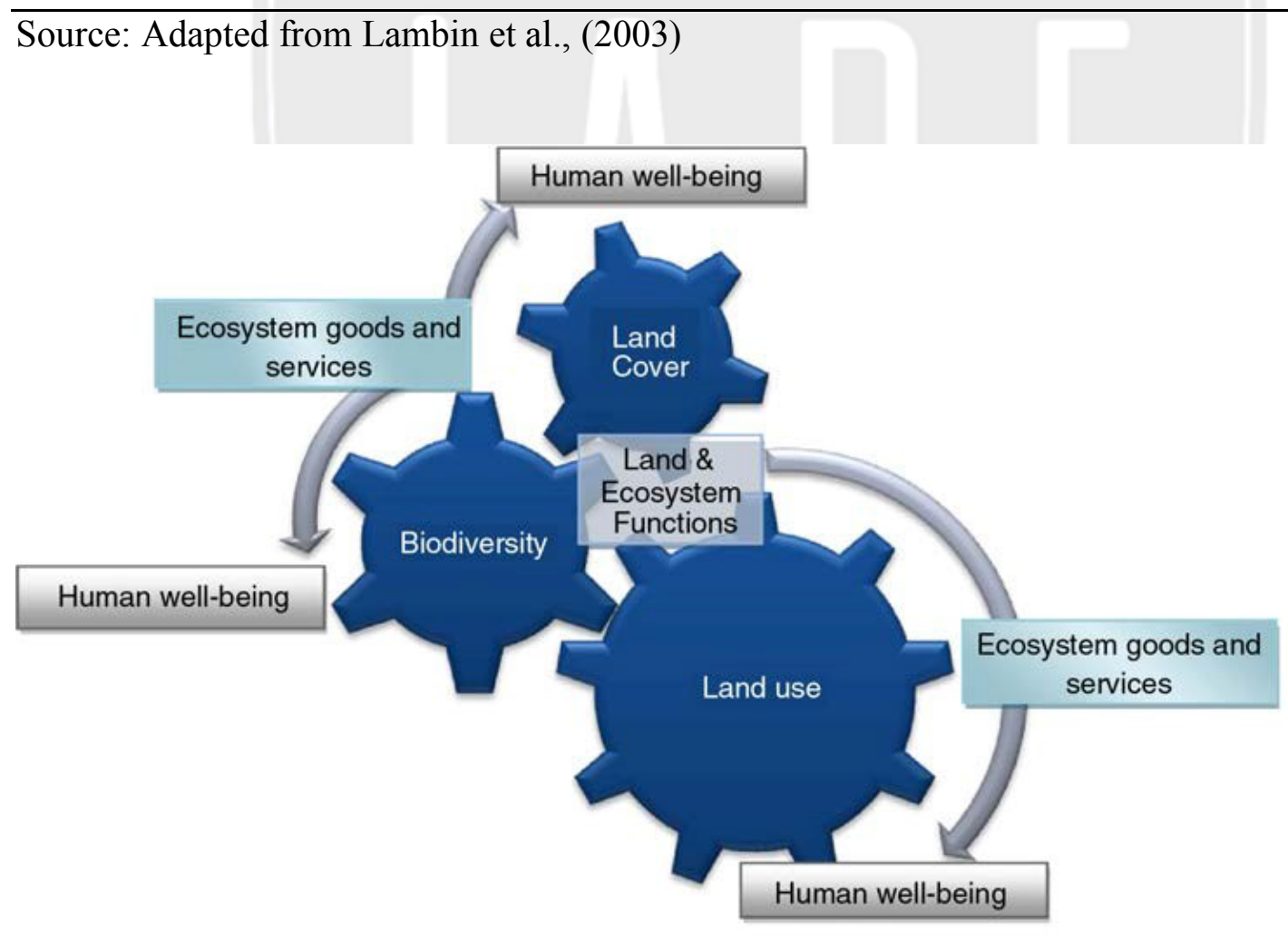

Source: Haines-Young, (2009)

Figure 1: Conceptual linkages between land cover/use change, biodiversity and land degradation 